\title{
Differences in fungal contamination of broiler litter between summer and winter fattening periods
}

\author{
Mario Ostović ${ }^{1}$, Ivica Ravić2 , Matija Kovačić3, Anamaria Ekert Kabalin ${ }^{4}$, Kristina Matković1 \\ Ivana Sabolek ${ }^{1}$, Željko Pavičić ${ }^{1}$, Sven Menčik ${ }^{4}$, and Danijela Horvatek Tomić ${ }^{5}$ \\ ${ }^{1}$ University of Zagreb Faculty of Veterinary Medicine, Department of Animal Hygiene, Behaviour and Welfare, \\ Zagreb, Croatia \\ 2 Veterinary Department, Mostar, Bosnia and Herzegovina \\ ${ }^{3}$ Kovačić Family Farm, Šopron, Kalnik, Croatia \\ ${ }^{4}$ University of Zagreb Faculty of Veterinary Medicine, Department of Animal Breeding and Livestock Production, Zagreb, Croatia \\ ${ }^{5}$ University of Zagreb Faculty of Veterinary Medicine, Department of Poultry Diseases with Clinic, Zagreb, Croatia
}

[Received in November 2020; Similarity Check in November 2020; Accepted in May 2021]

This study aimed to compare fungal contamination of poultry litter between warm and cold seasons. It was carried out in commercial production conditions over two five-week fattening periods: one in the summer (July-August) and one in the winter (December-January). Broilers were reared on a litter composed of chopped straw and sawdust. Litter fungal concentration and composition were investigated weekly, along with litter temperature, moisture, and $\mathrm{pH}$. Litter concentration of total fungi increased over both fattening periods, with no differences in median concentrations between them. Season also had no effect on yeast, Aspergillus section Nigri, and Cladosporium, Fusarium, and Rhizopus spp. concentrations, while the Aspergillus section Flavi and Aspergillus spp. combined showed higher concentrations in the summer, and Mucor and Penicillium spp. in the winter. Total fungal concentration highly correlated with litter temperature, moisture, and $\mathrm{pH}$, regardless of the season. Our findings can be useful in the assessment and control of potential harmful effect of fungi on the health of poultry and poultry farm workers.

KEY WORDS: cold season; moisture; mycoflora; $\mathrm{pH}$; poultry; temperature; warm season

Poultry/broiler litter is a bedding material, usually straw in Europe, mixed with excreta, spilled feed/water, and feathers, whose quality is important for broiler welfare and productivity as it absorbs moisture, dilutes faecal content, and serves as a thermal insulator and protective cushion between broilers and the floor (1-4).

However, it is also known to favour fungal growth (5), which is why its quality should be monitored continuously, mostly by moisture assessment. In the initial fattening period, the level of broiler litter moisture is $10-15 \%$, which by the end of this period rises to $25-50 \%$. Recommended levels span between $30 \%$ and $40 \%$ (6-8). Other recommended conditions include neutral $\mathrm{pH}$, low ammonia production, and loose, crust-free litter. High moisture leads to litter caking that favours ammonia release, whereas low moisture favours respiratory problems due to high levels of dust that carries microorganisms, including fungal spores $(3,9)$. Another crucial condition for the biochemical process of litter ripening is litter temperature, which depends on air temperature in a broiler house $(7,10)$.

Corresponding author: Mario Ostović, University of Zagreb Faculty of Veterinary Medicine, Department of Animal Hygiene, Behaviour and Welfare, Heinzelova 55, 10000 Zagreb, Croatia, E-mail: mostovic@vef.hr
Compared to bacterial and viral diseases, fungal diseases are less prevalent in poultry but often devastating when they break out $(11,12)$. Fungi can cause disease directly or with mycotoxins they produce, which usually enter the body by ingestion and cause poisoning and immunosuppression. This can lead to great economic losses through loss of meat and egg production $(13,14)$.

Fungal diseases in poultry have come into focus all over the world due to overuse of antibiotics, which eliminate innate bacterial microflora and give way to infections with opportunistic pathogens (14). In addition, fungal infections in poultry are very difficult and expensive to treat, as vaccines are not available, and resistance to drugs is increasing, which makes prognosis uncertain. Therefore, the best way to fighting these diseases is prevention $(5,12$, 15). Prevention is also important as a way to minimise zoonosis implications (16-19).

One of the first steps in that direction is to determine the composition and concentration of mycoflora in poultry litter as a way to assess the risks, especially if poultry litter is later to be used to fertilise open fields, as it can get airborne and affect neighbouring rural areas $(9,20)$.

Yet, only a few studies have investigated fungal contamination of poultry litter (e.g., 9, 21-26) and reports

M. Ostović and D. Horvatek Tomić contributed equally to this work. 
on seasonal concentrations and incidence of diseases are inconsistent and mainly focused on Aspergillus spp. as the most important pathogen from the health and economic viewpoint $(23,26-32)$.

The aim of our study was to get a broader picture of fungal contamination (than limiting ourselves to Aspergillus spp.) by investigating seasonal fungal flora in poultry litter and test the following hypotheses: (i) the season will influence total fungal concentrations and composition in the litter, and (ii) fungal concentrations will depend on other parameters of litter quality, such as temperature, moisture, and $\mathrm{pH}$.

\section{MATERIALS AND METHODS}

The study protocol was approved by the Ethics Committee in Veterinary Medicine of the University of Zagreb Faculty of Veterinary Medicine, Zagreb, Croatia (class: 640-01/16-17/43; record no.: 251-61-01/139-16-2; 21 April 2016).

\section{Study design, animals, and farm management}

The study was conducted in commercial farming conditions in a broiler house over the five-week production cycles in the summer (July-August 2016) and winter (December-January 2016/2017). During each production cycle, 18,000 Ross hybrid broilers were kept in controlled conditions on a $10-\mathrm{cm}$ thick litter made of a $2-\mathrm{cm}$ bottom pine sawdust layer and a $8-\mathrm{cm}$ wheat straw layer (up to $33 \mathrm{~kg} / \mathrm{m}^{2}$ stocking density). The broiler house used straw from its own farming fields (chopped to the length of $5 \mathrm{~cm}$ ) and sawdust from a sawmill (neither dedusted nor disinfected). Litter was neither turned over nor additional amount of litter was added during either production cycle. The broiler house has an oil heater, negative pressure mechanical ventilation, and lighting as recommended for Ross hybrids (33). Broilers were fed complete feed mix (Biodar, Varaždin, Croatia) from round pan feeders and watered from nipple drinkers with cups. Feed and water were provided ad libitum.

The broiler house is cleaned and disinfected with highpressure cleaners between production cycles, which are separated by a two-week house rest. Floors are disinfected with caustic soda (PCC Rokita SA, Brzeg Dolny, Poland) and the rest of the house, including equipment, with Ecocid ${ }^{\mathbb{B}}$ $\mathrm{S}$ (Krka d.d., Novo Mesto, Slovenia). Once the litter is spread, the house is fumigated with a Formaster G tablet (Formaster di Emanuela Magnani \& C.s.a.s., Piacenza, Italy).

Litter fungal contamination, temperature, moisture, and $\mathrm{pH}$ were determined once a week over the five-week production cycles.

\section{Litter sampling and analytical methods}

Litter temperature $\left({ }^{\circ} \mathrm{C}\right)$ was measured with a Testo 925 thermocouple thermometer (Testo SE \& Co. KGaA, Lenzkirch, Germany) at $3 \mathrm{~cm}$ below litter surface at five points of the broiler house (four corners and one in the centre). At these points we also took one litter sample per point into sterile bags (Aptaca Spa, Canelli, Italy) and transported them to the laboratory for analysis on the same day. Litter moisture (\%) was determined using the gravimetric method by calculating weight loss after drying, whereas $\mathrm{pH}$ was determined electrometrically using a WTW inoLab pH 720 pH meter (Wissenschaftlich-Technische Werkstätten $\mathrm{GmbH}$, Weilheim, Germany). More detailed descriptions are available elsewhere $(8,34)$.

Litter fungal contamination was determined as follows: $10 \mathrm{~g}$ of each sample was first diluted 10 -fold with sterile distilled water and then $100 \mu \mathrm{L}$ of the dilution plated on Sabouraud dextrose agar (Biolife, Milan, Italy) and incubated at $25^{\circ} \mathrm{C}$ for 5-7 days. The fungi were identified based on macroscopic appearance of grown colonies and on microscopic examination of spores stained with lactophenol blue solution (Sigma-Aldrich, St. Louis, MO, USA) $(35,36)$. The concentration was expressed as colony forming units per gram of litter (CFU/g). Analytical procedures were performed in triplicate.

\section{Statistical analysis}

All data were analysed with Statistica v. 13.5 (TIBCO Software Inc., Palo Alto, CA, USA, 2018). The normality of data distribution was tested with the KolmogorovSmirnov test. The significance of differences in median litter fungal concentrations between summer and winter measurements was tested with the Mann-Whitney $U$-test. Differences in mean litter temperature, moisture, and $\mathrm{pH}$ and differences between weekly measurements of all parameters between the seasons were compared with Student's $t$-test. Differences between weekly measurements within one season were tested with the repeated-measures ANOVA and post-hoc Tukey HSD test. Correlations between fungal concentrations and litter temperature, moisture, and $\mathrm{pH}$ were assessed with Spearman rank-order correlation. In all tests, the level of statistical significance was set at $P<0.05$.

\section{RESULTS AND DISCUSSION}

Litter fungal concentrations ranged from $10^{2}$ to $10^{5}$ $\mathrm{CFU} / \mathrm{g}$, which is consistent with previous reports $(9,21$, 37-39), and increased with time (fattening weeks), as expected (39). We found no significant seasonal differences at the beginning and the end of the fattening periods (Figure 1) or in the median fungal concentrations for either period (Table 1). This is because fungal concentrations highly correlated with litter moisture and $\mathrm{pH}$ throughout the study 


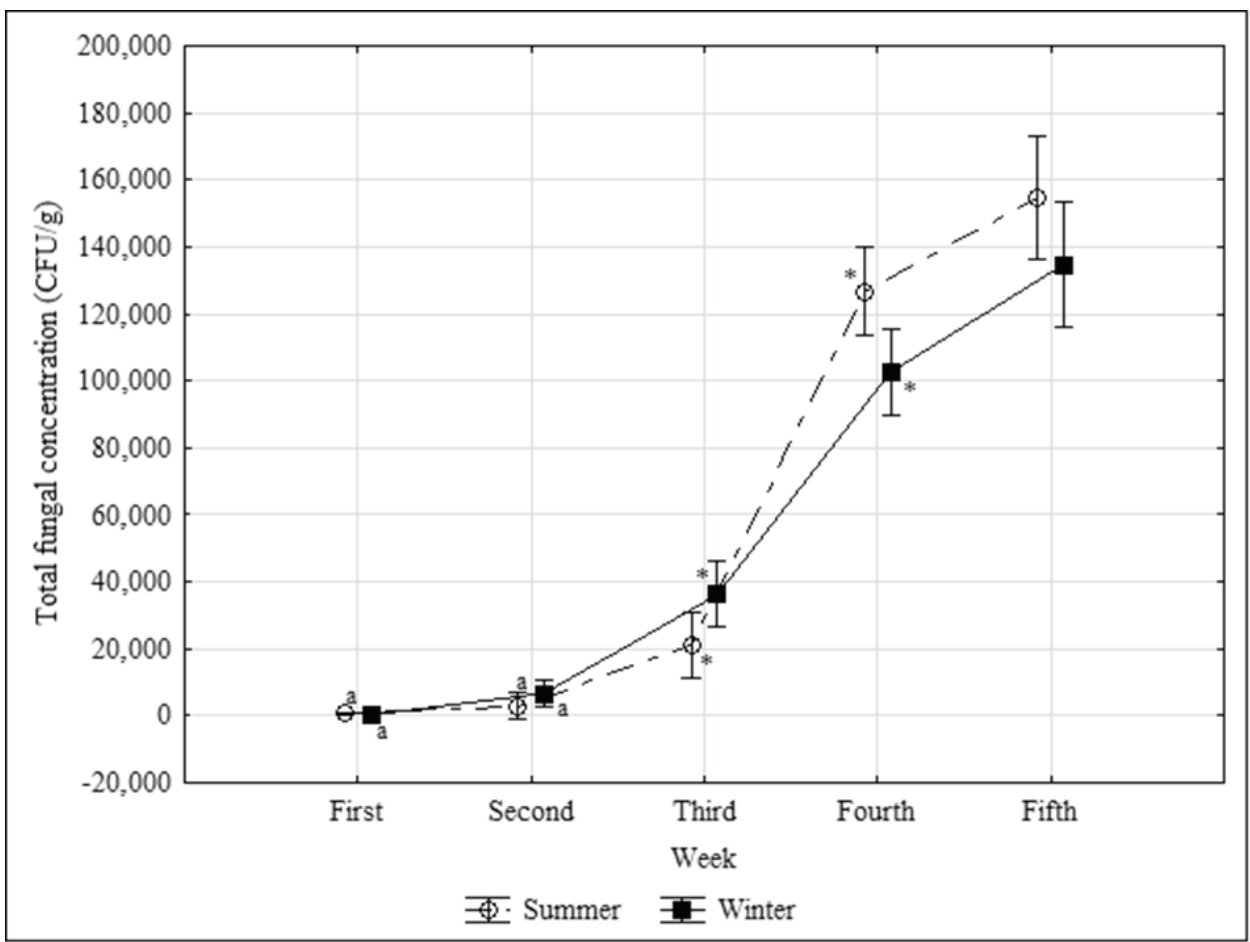

Figure 1 Comparison of weekly total fungal concentrations in broiler litter between the summer and winter fattening periods (values are expressed as means $\pm 95 \%$ confidence intervals). ${ }^{a}$ marks weekly values of the same season that did not differ significantly; other values differed significantly $(P<0.05)$. " weekly values that differed significantly between the seasons $(P<0.05)$. CFU - colony forming units

(Table 2), which did not significantly differ between the seasons (Table 1). The correlation between fungal growth and litter moisture and $\mathrm{pH}$ was also reported by Hutson (40) and Schefferle (41), but there are reports to the contrary as well (38). According to Arné et al. (5), the impact of variations in litter moisture and $\mathrm{pH}$ on fungal population density remains a controversial issue, although wet and soiled areas can intensify fungal growth.

Even though the five-week fattening periods in our study were shorter than in the above studies, and higher litter moisture and $\mathrm{pH}$ were recorded in the last week of both periods, the comparison makes sense, as according to Milanov et al. (25) microorganism growth (including fungal) in broiler litter reaches its peak in about one month of fattening, after which it declines and reaches steady levels.

We also found a highly significant correlation between fungal concentrations and litter temperature (Table 2), which increased with time in both seasons (Figure 2), yielding values consistent with the reports by Spindler and Hartung (42) and Knížatová et al. (43). However, the latter study found no major differences in litter temperature between summer and winter fattening periods, whereas we did (Table 1, Figure 2). Despite controlled conditions in the broiler house, this was likely related to seasonal differences in outdoor temperature. Even so, it seems that the five-week fattening periods in our study were too short for the differences in litter temperature to cause seasonal differences in fungal concentrations or to affect litter moisture and/or $\mathrm{pH}$.

Litter moisture and $\mathrm{pH}$ in our study increased over both seasons as weeks went by (Figures 3 and 4) and were consistent with other studies of straw as a litter material (44-46). Their mean values did not significantly differ between the seasons (Table 1), save for the higher moisture level in the last fattening week of the winter fattening

Table 1 Comparison of total litter fungal concentrations, temperature, moisture, and $\mathrm{pH}$ between the summer and winter broiler fattening periods

\begin{tabular}{|c|c|c|c|c|}
\hline Parameter & & Summer & Winter & $P$ \\
\hline Fungi (CFU/g) & $\begin{array}{l}\text { Median } \\
\text { (range) }\end{array}$ & $\begin{array}{c}1.82 \times 10^{4} \\
\left(3.00 \times 10^{2}-1.65 \times 10^{5}\right)\end{array}$ & $\begin{array}{c}3.32 \times 10^{4} \\
\left(2.00 \times 10^{2}-1.58 \times 10^{5}\right) \\
\end{array}$ & 0.62 \\
\hline Temperature $\left({ }^{\circ} \mathrm{C}\right)$ & $\begin{array}{l}\text { Mean } \pm \text { SD } \\
\text { (range) }\end{array}$ & $\begin{array}{c}28.80 \pm 1.74 \\
(25.60-31.80)\end{array}$ & $\begin{array}{c}26.34 \pm 1.75 \\
(22.90-29.80)\end{array}$ & $<0.001$ \\
\hline Moisture (\%) & $\begin{array}{l}\text { Mean } \pm \text { SD } \\
\text { (range) }\end{array}$ & $\begin{array}{l}28.18 \pm 10.12 \\
(7.90-42.30)\end{array}$ & $\begin{array}{c}32.17 \pm 11.07 \\
(12.60-49.00)\end{array}$ & 0.19 \\
\hline $\mathrm{pH}$ & $\begin{array}{l}\text { Mean } \pm \text { SD } \\
\text { (range) }\end{array}$ & $\begin{array}{c}7.06 \pm 1.18 \\
(4.95-8.71)\end{array}$ & $\begin{array}{c}6.83 \pm 1.23 \\
(5.42-8.61)\end{array}$ & 0.50 \\
\hline
\end{tabular}

$\overline{\mathrm{CFU}}$ - colony forming units. Significant difference is marked in bold type 


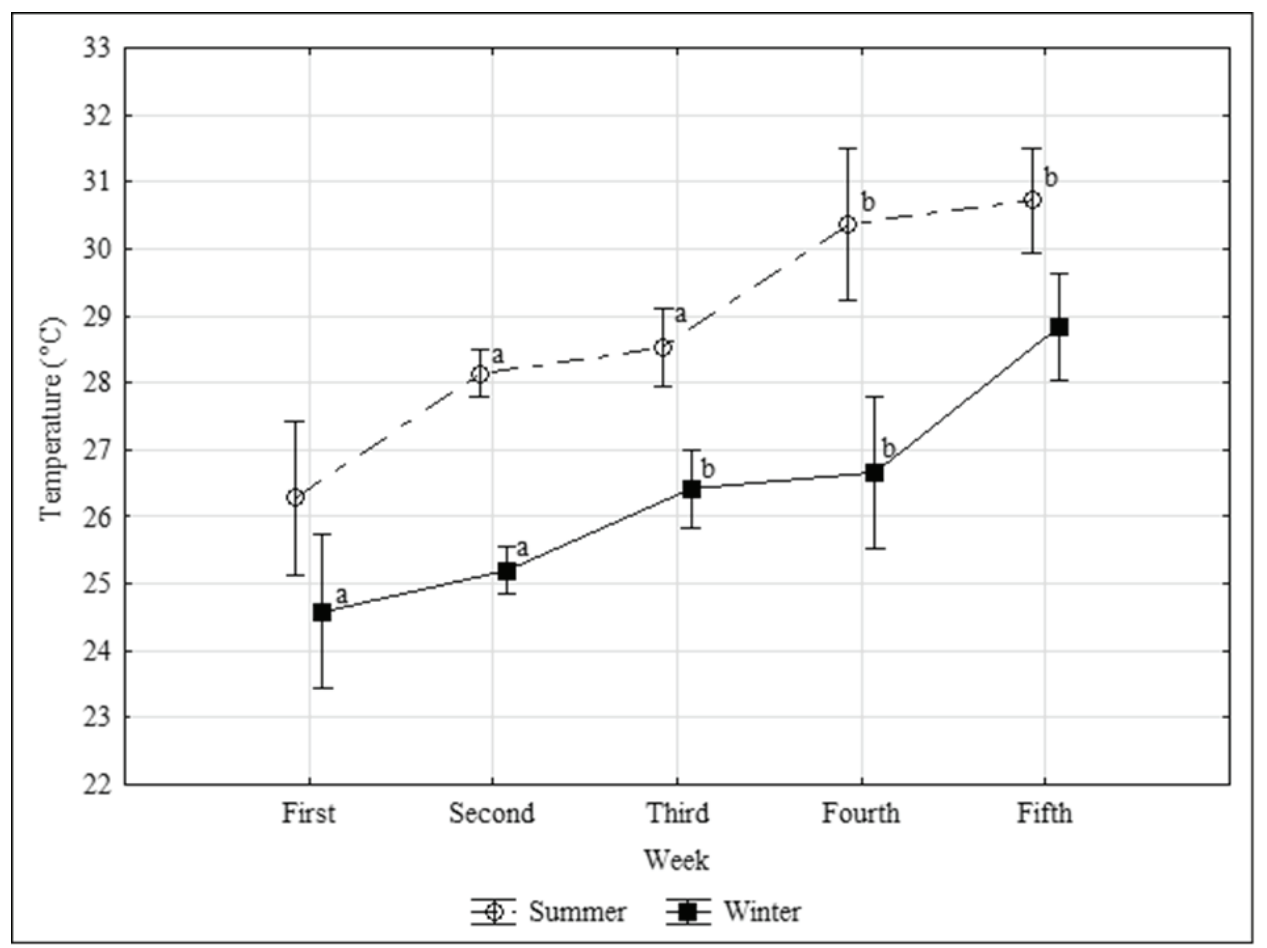

Figure 2 Comparison of weekly broiler litter temperatures between the summer and winter fattening periods (values are expressed as means $\pm 95 \%$ confidence intervals). ${ }^{\mathrm{a}, \mathrm{b}}$ same letters mark weekly values of the same season that did not differ significantly; other values differed significantly $(P<0.05)$. All weekly values differed significantly between the seasons $(P<0.05)$

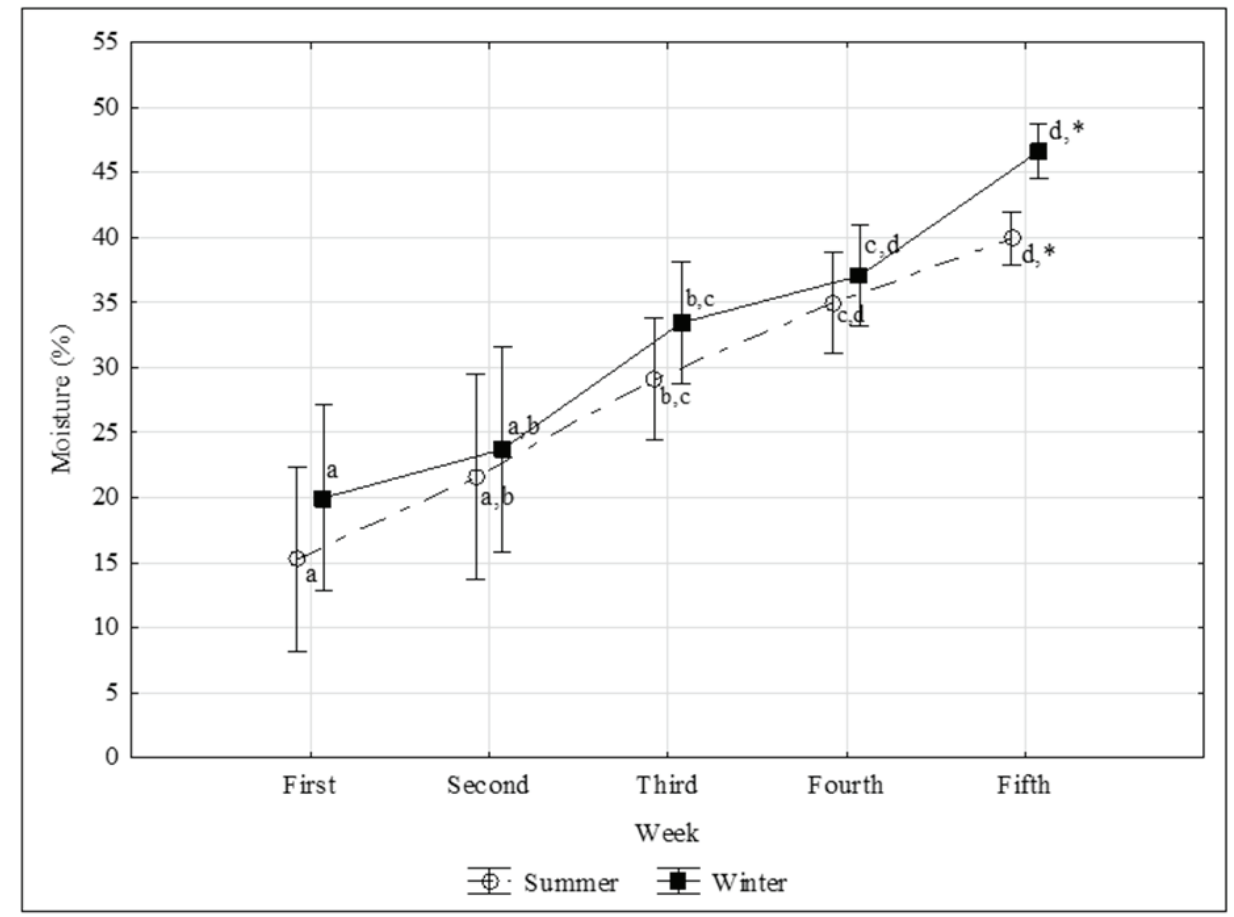

Figure 3 Comparison of weekly broiler litter moisture between the summer and winter fattening periods (values are expressed as means $\pm 95 \%$ confidence intervals). a,b,c,d same letters mark weekly values of the same season that did not differ significantly; other values differed significantly $(P<0.05)$. ${ }^{*}$ weekly values that differed significantly between the seasons $(P<0.05)$ 
Table 2 Correlations between total litter fungal concentrations and litter temperature, moisture, and $\mathrm{pH}$

\begin{tabular}{lccc}
\hline Parameter & Temperature $\left({ }^{\circ} \mathbf{C}\right)$ & Moisture (\%) & pH \\
\hline Fungi $(\mathrm{CFU} / \mathrm{g})$ & $0.710^{*}$ & $0.791^{*}$ & $0.918^{*}$ \\
\hline
\end{tabular}

$\overline{\mathrm{CFU}}$ - colony forming units. ${ }^{*} P<0.05$

Table 3 Comparison of litter fungal composition (with concentrations by genera/sections) between the summer and winter broiler fattening periods

\begin{tabular}{|l|c|c|c|}
\hline \multirow{2}{*}{ Fungal genera } & \multicolumn{2}{|c|}{$\begin{array}{c}\text { CFU/g } \\
\text { Median (range) }\end{array}$} & \multirow{2}{*}{ P } \\
\cline { 2 - 4 } & Summer & $0\left(0-5.00 \times 10^{2}\right)$ & $<\mathbf{0 . 0 1}$ \\
\hline Aspergillus spp. & $2.00 \times 10^{2}\left(0-1.40 \times 10^{3}\right)$ & Not detected & $<\mathbf{0 . 0 0 1}$ \\
\hline A. section Flavi & $1.00 \times 10^{2}\left(0-1.00 \times 10^{3}\right)$ & $0\left(0-5.00 \times 10^{2}\right)$ & 0.18 \\
\hline A. section Nigri & $1.00 \times 10^{2}\left(0-1.40 \times 10^{3}\right)$ & Not detected & 0.82 \\
\hline Cladosporium spp. & $0\left(0-1.00 \times 10^{2}\right)$ & $0\left(0-1.00 \times 10^{2}\right)$ & 0.82 \\
\hline Fusarium spp. & Not detected & $1.00 \times 10^{2}\left(0-2.90 \times 10^{4}\right)$ & $<\mathbf{0 . 0 0 1}$ \\
\hline Mucor spp. & Not detected & $1.50 \times 10^{3}\left(0-2.85 \times 10^{4}\right)$ & $<\mathbf{0 . 0 0 1}$ \\
\hline Penicillium spp. & $0\left(0-4.00 \times 10^{2}\right)$ & $0\left(0-2.00 \times 10^{2}\right)$ & 0.83 \\
\hline Rhizopus spp. & $0\left(0-1.00 \times 10^{2}\right)$ & $9.20 \times 10^{3}\left(0-1.35 \times 10^{5}\right)$ & 0.19 \\
\hline Yeasts & $1.71 \times 10^{4}\left(0-1.64 \times 10^{5}\right)$ & $0(0-50)$ & $\mathbf{0 . 0 3}$ \\
\hline Unidentified & $0\left(0-1.00 \times 10^{3}\right)$ & & \\
\hline
\end{tabular}

$\mathrm{CFU}$ - colony forming units. Significant differences are marked in bold type

(Figure 3). Comparing different materials for broiler litter between summer and winter fattening periods, Garcia et al. (47) reported higher moisture for straw in the summer and higher $\mathrm{pH}$ in the winter, which may be owed to different farm management in their study. Previous studies have revealed that litter moisture also depends on litter quantity, stocking density, watering system, ventilation, indoor microclimate, broiler age, nutrition, and health (enteritis) $(48,49)$. Even though we did not keep track of broiler health, no enteritis outbreaks were recorded in either season.

Our findings have shown a prevalence of yeasts in broiler litter, with no significant seasonal difference (Table $3)$, as also reported by other studies $(23,25,26,37)$.

Besides yeasts, the most prevalent fungal species detected in our study were Aspergillus (encompassing the Flavi and Nigri sections), Mucor, and Penicillium spp. (Table 3), which is in line with previous reports $(9,22$, 37-39, 50, 51). These three also showed significant seasonal differences. Aspergillus spp. combined, including $A$. section Flavi, were more frequent in the summer, and Mucor and Penicillium spp. in the winter. Other species showed no seasonal differences (Table 3). Soliman et al. (23) also found Aspergillus spp. to prevail in closed broiler houses in the summer and Penicillium spp. in the winter, but unlike our study, theirs reported Mucor spp. to be more prevalent in the summer.

Some studies using same methodology for fungal identification detected more mould genera, including Aspergillus sections, than we did $(9,37,38)$, most likely because of different litter material. This suggests that straw litter, known to have higher moisture, $\mathrm{pH}$, and temperature than other materials $(44,52-54)$, favours the development of more homogeneous mycoflora.
Even though we used the same methods for fungal identification as Chollom et al. (24), we did not find any dermatophytes in the litter, which are of particular health concern. Their finding of high Trichophyton spp. prevalence in poultry litter may be owed to higher incubation temperature than in our study, but may also point to our less precise fungal identification.

Nevertheless, several fungal genera isolated in our study pose a health risk both as pathogens or producers of mycotoxins, which can cause severe poisoning in humans and animals (55), Aspergillus spp. in particular.

Aspergillus fumigatus (section Fumigati) is the most pathogenic fungus affecting poultry, accounting for $95 \%$ of all cases of aspergillosis, but other species, such as $A$. flavus (section Flavi), A. niger (section Nigri), A. nidulans (section Nidulantes), and A. terreus (section Terrei), alone or combined, also present a health risk $(14,56,57)$. Besides birds, Aspergillus species are known opportunistic pathogens in humans, immunocompromised patients in particular. Aspergillus fumigatus accounts for over $80 \%$ of diseases, including invasive pulmonary aspergillosis, aspergilloma, and different forms of hypersensitivity disorders such as allergic asthma, allergic sinusitis, pneumonitis, and allergic bronchopulmonary aspergillosis (58-60). Another species with emerging evidence of a broad spectrum of infections that are difficult to treat are the Fusarium spp., which can cause onychomycosis, skin infections, and keratitis (61). We did not find any species from the Aspergillus section Fumigati in our litter samples, regardless of the season, while Fusarium spp. was detected in the winter (Table 3).

As regards the risk of mycotoxin poisoning, $A$. sections Flavi and Nigri, and Fusarium and Penicillium spp. we 


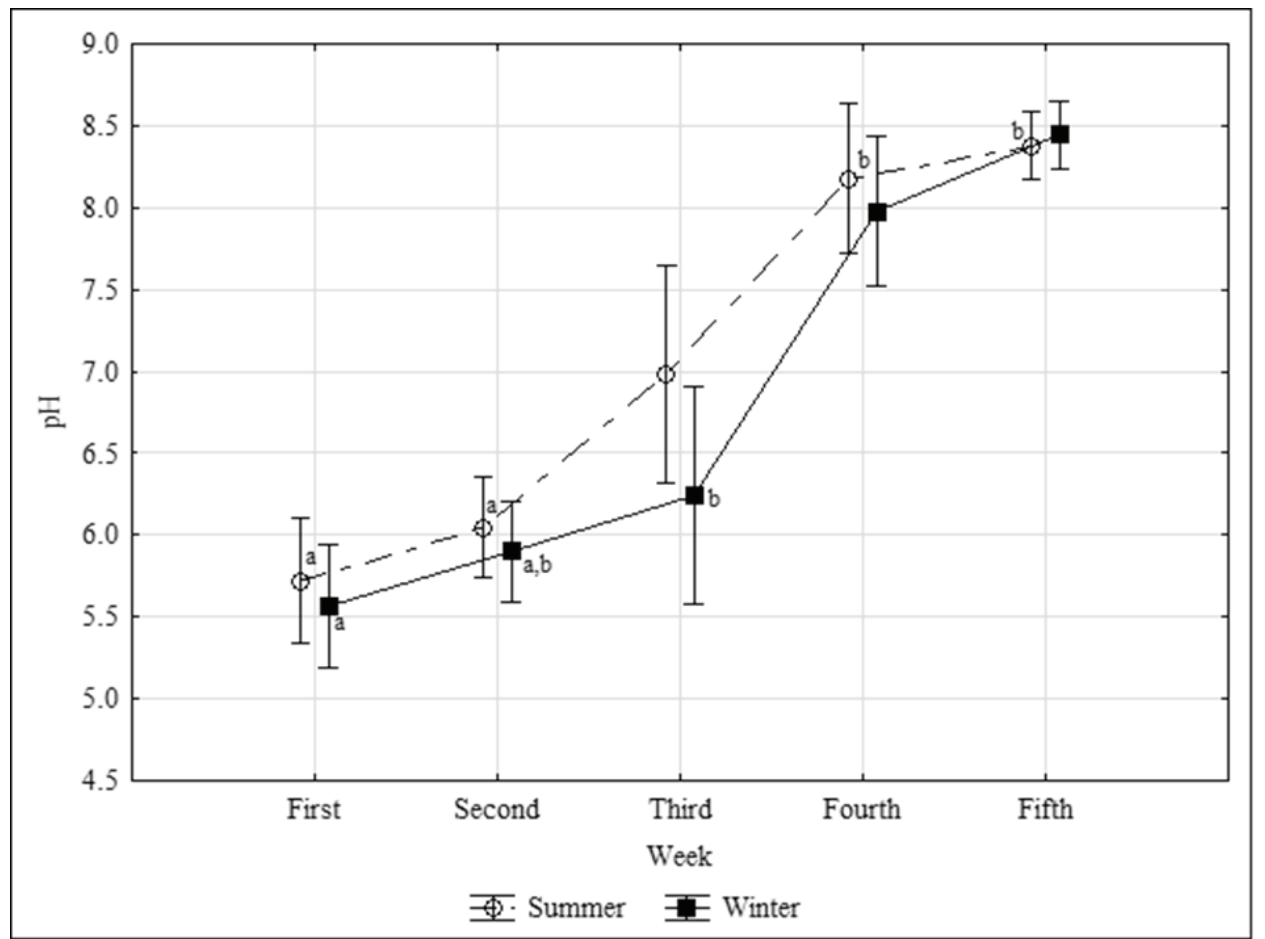

Figure 4 Comparison of weekly broiler litter $\mathrm{pH}$ between the summer and winter fattening periods (values are expressed as means \pm $95 \%$ confidence intervals). ${ }^{\mathrm{a}, \mathrm{b}}$ same letters mark weekly values of the same season that did not differ significantly; other values differed significantly $(P<0.05)$. No weekly values differed significantly between the seasons

found in our litter samples (Table 3) are known mycotoxin producers $(62,63)$.

\section{CONCLUSIONS}

Our findings suggest that season does not influence total fungal concentrations as much as fungal composition in broiler litter. They have also confirmed that fungal concentrations much depend on litter temperature, moisture, and $\mathrm{pH}$ and can be useful in the assessment and control of potential adverse effects on poultry and poultry farm workers.

To the best of our knowledge, other studies did not compare fungal contamination of broiler litter on the same farm between seasons. Furthermore, our study contributes to the scarce data available on straw as litter material in broiler rearing. What limits the interpretation of our findings is that they do not distinguish enough fungal isolates at the species level, as we used methods specific enough to allow comparison with the results of other studies investigating poultry litter mycoflora. Future studies should observe various litter materials in the same production conditions across seasons with more specific identification of fungi, including the use of sensitive methods of genotyping.

\section{Conflicts of interest}

None to declare.

\section{REFERENCES}

1. Meluzzi A, Sirri F. Welfare of broiler chickens. Ital J Anim Sci 2009;8(Suppl 1):161-73. doi: 10.4081/ijas.2009.s1.161

2. De Jong I, Berg C, Butterworth A, Estevéz I. Scientific report updating the EFSA opinions on the welfare of broilers and broiler breeders. Supporting Publications 2012:EN-295 [displayed 7 October 2020]. Available at https://www.efsa. europa.eu/en/supporting/pub/en-295. doi: 10.2903/sp. efsa.2012.EN-295

3. Sabolek I, Nejedli S, Matković K, Pavičić Ž, Ostović M. Pregled dosadašnjih spoznaja o utjecaju visine stelje na pojavnost kontaktnog dermatitisa u tovnih pilića [A review on the impact of litter depth on the occurrence of contact dermatitis in broilers, in Croatian]. Meso 2020;22:378-85.

4. Ritz CW, Fairchild BD, Lacy MP. Litter quality and broiler performance. Bulletin 1267. Reviewed April, 2009. Cooperative Extension Service. Athens: The University of Georgia, College of Agricultural and Environmental Sciences. p. 1-7 [displayed 7 October 2020]. Available at https:// athenaeum.libs.uga.edu/bitstream/handle/10724/12466/ B1267.pdf?sequence $=1$

5. Arné P, Thierry S, Wang D, Deville M, Le Loc'h G, Desoutter A, Féménia F, Nieguitsila A, Huang W, Chermette R, Guillot J. Aspergillus fumigatus in poultry. Int J Microbiol 2011;2011:746356. doi: 10.1155/2011/746356

6. Benito LM. La problemática de las camas húmedas en las granjas de broilers [The issue of wet litter on broiler farms, in Spanish]. Selecciones Avícolas 1991;33:437-52.

7. Žužul S, Ostović M, Matković K, Pavičić Ž, Tršan J, Mikulić M, Ravić I. Uloga duboke stelje u tovu pilića i svinja [The role of deep litter in broiler and pig fattening, in Croatian]. Meso 2017;19:223-8. 
8. Abreu VMN, de Abreu PG, Jaenisch FRF, Coldebella A, de Paiva DP. Effect of floor type (dirt or concrete) on litter quality, house environmental conditions, and performance of broilers. Rev Bras Cienc Avic 2011;13:127-37. doi: 10.1590/S1516635X2011000200007

9. Viegas C, Carolino E, Malta-Vacas J, Sabino R, Viegas S, Veríssimo C. Fungal contamination of poultry litter: a public health problem. J Toxicol Environ Health A 2012;75:1341-50. doi: $10.1080 / 15287394.2012 .721165$

10. Ivoš J, Asaj A, Marjanović LJ, Madžirov Ž. A contribution to the hygiene of deep litter in the chicken house. Poult Sci 1966:45:676-83. doi: 10.3382/ps.0450676

11. Asfaw M, Dawit D. Review on major fungal disease of poultry. Br J Poult Sci 2017;6:16-25. doi: 10.5829/idosi.bjps.2017.16.25

12. Swayne DE, Glisson JR, McDougald LR, Nolan LK, Suarez DL, Nair VL, editors. Diseases of Poultry. $13^{\text {th }}$ ed. Ames: Wiley-Blackwell, A John Wiley \& Sons, Inc.; 2013.

13. Jand SK, Kaur P, Sharma NS. Mycoses and mycotoxicosis in poultry: a review. Indian J Anim Sci 2005;75:465-76.

14. Dhama K, Chakraborty S, Verma AK, Tiwari R, Barathidasan R, Kumar A, Singh SD. Fungal/mycotic diseases of poultrydiagnosis, treatment and control: a review. Pak J Biol Sci 2013;16:1626-40. doi: 10.3923/pjbs.2013.1626.1640

15. Sokolović M, Šimpraga B, Krstulović F, Berendika M. Značaj patogenih plijesni u peradarstvu [Significance of pathogenic moulds in poultry production; in Croatian]. In: Balenović M, editor. Proceedings of the XI Symposium Poultry Days 2015 with International Participation; 13-16 May 2015; Šibenik, Croatia. Zagreb: Croatian Veterinary Institute, Poultry Centre; 2015. p. 32-8.

16. Gigli ACS, Baracho MS, Nääs IA, Silva RA, Zago R, Dall'anese FP. Diagnosis and evaluation of fungi presence in the air of two different ventilation systems for broiler houses. Rev Bras Cienc Avic 2005;7:205-8. doi: 10.1590/S1516635X2005000400002

17. Prester Lj, Macan J, Matković K, Vučemilo M. Determination of Aspergillus fumigatus allergen 1 in poultry farms using the enzyme immunoassay. Arh Hig Rada Toksikol 2010;61:16773. doi: 10.2478/10004-1254-61-2010-2004

18. Rimac D, Macan J, Varnai VM, Vučemilo M, Matković K, Prester Lj, Orct T, Trošić I, Pavičić I. Exposure to poultry dust and health effects in poultry workers: impact of mould and mite allergens. Int Arch Occup Environ Health 2010;83:9-19. doi: 10.1007/s00420-009-0487-5

19. Miskiewicz A, Kowalczyk P, Oraibi SM, Cybulska K, Misiewicz A. Bird feathers as potential sources of pathogenic microorganisms: a new look at old diseases. Antonie Van Leeuwenhoek 2018;111:1493-507. doi: 10.1007/s10482-0181048-2

20. Kyakuwaire M, Olupot G, Amoding A, Nkedi-Kizza P, Basamba TA. How safe is chicken litter for land application as an organic fertilizer? A review. Int J Environ Res Public Health 2019;16:3521. doi: 10.3390/ijerph16193521

21. Yardimci M, Kenar B. Effect of stocking density on litter microbial load in broiler chickens. Arch Zootech 2008;11:75-81.

22. Khosravinia H, Gharoni MH, Darvishnia M. Litter mycology and the impacts of litter type and preslaughter feed withdrawal on crop bacterial community in broiler chicken. Afr J Microbiol Res 2009;3:844-50.

23. Soliman ES, Sobeih MAA, Ahmad ZH, Hussein MM, AbdelLatiff H, Moneim AA. Seasonal epidemiological surveillance on bacterial and fungal pathogens in broiler farms in Egypt. Int J Poult Sci 2009;8:720-7. doi: 10.3923/ijps.2009.720.727

24. Chollom SC, Agada GO, Tyem DA, Idu MU, Timothy V, Chukwu DI, Okwori AJ. Potential public health hazard of the mycoflora of poultry litter in some selected poultry farms in Jos, Nigeria. AJST 2013;4:64-6.

25. Milanov D, Knežević S, Vidaković S, Pajić M, Živkov-Baloš M, Aleksić N. Microbial contamination of poultry litter during fattening period. Biotechnol Anim Husb 2019;35:253-65. doi: 10.2298/BAH1903253M

26. Debey MC, Trampel DW, Richard JL, Bundy DS, Hoffman LJ, Meyer VM, Cox DF. Effect of environmental variables in turkey confinement houses on airborne Aspergillus and mycoflora composition. Poult Sci 1995;74:463-71. doi: 10.3382/ps.0740463

27. Sajid MA, Khan IA, Rauf U. Aspergillus fumigatus in commercial poultry flocks, a serious threat to poultry industry in Pakistan. J Anim Plant Sci 2006;16:79-81.

28. Sowiak M, Bródka K, Kozajda A, Buczyńska A, SzadkowskaStańczyk I. Fungal aerosol in the process of poultry breeding - quantitative and qualitative analysis. Med Pr 2012;63:1-10. PMID: 22774459

29. Lawniczek-Walczyk A, Górny RL, Golofit-Szymczak M, Niesler A, Wlazlo A. Occupational exposure to airborne microorganisms, endotoxins and $\beta$-glucans in poultry houses at different stages of the production cycle. Ann Agric Environ Med 2013;20:259-68. PMID: 23772571

30. Matković K, Vučemilo M, Štoković I, Šimić R, Marušić D, Vinković B, Matković S. Concentrations of airborne bacteria and fungi in a livestock building with caged laying hens. Vet Arh 2013;83:413-24.

31. Sultana S, Rashid SMH, Islam MN, Ali MH, Islam MM, Azam MG. Pathological investigation of avian aspergillosis in commercial broiler chicken at Chittagong district. Int J Innov Appl Stud 2015;10:366-76.

32. Seifi S, Shokri H, Karimi Madab M. Isolation and characterization of mycoflora of chicken hatcheries in Mazandaran province, north of Iran. Vet Res Forum 2018;9:373-8. doi: 10.30466/vrf.2018.33106

33. Aviagen. Ross Broiler Management Handbook 2018 [displayed 15 September 2020]. Available at http://en.aviagen. com/assets/Tech Center/Ross Broiler/RossBroilerHandbook2018-EN.pdf

34. Brauer-Vigoderis R, Ferreira-Tinôco IF, Pandorfi H, BastosCordeiro M, Souza-Júnior JP de, de Carvalho-Guimarães MC. Effect of heating systems in litter quality in broiler facilities in winter conditions. Dyna (Medellin) 2014;81:36-40. doi: 10.15446/dyna.v81n185.35762

35. de Hoog GS, Guarro J, Gené J, Figueras MJ. Atlas of Clinical Fungi. $2^{\text {nd }}$ ed. Utrecht: Centraalbureau voor Schimmelcultures; 2000.

36. Samanta I. Veterinary Mycology. New Delhi: Springer; 2015.

37. Dennis C, Gee JM. The microbial flora of broiler-house litter and dust. J Gen Microbiol 1973;78:101-7. doi: 10.1099/00221287-78-1-101

38. Lovett J, Messer JW, Read RB Jr. The microflora of southern Ohio poultry litter. Poult Sci 1971;50:746-51. doi: 10.3382/ ps.0500746

39. Bacon CW, Burdick D. Growth of fungi in broiler houses. Poult Sci 1977;56:653-61. doi: 10.3382/ps.0560653

40. Hutson LR. Bagasse litter as a contributory factor in avian aspergillosis. Can Vet J 1966;7:117-20. PMID: 5949595 
41. Schefferle HE. The microbiology of built up poultry litter. J Appl Bacteriol 1965;28:403-11. doi: 10.1111/j.1365-2672.1965. tb02170.x

42. Spindler B, Hartung J. Assessment of litter quality in broiler houses. In: Briese A, Clauß M, Hartung J, Springorum A, editors. Proceedings of the $14^{\text {th }}$ Congress of the International Society for Animal Hygiene (ISAH); 19-23 Jul 2009; Vechta, Germany. Brno: Tribun EU; 2009. p. 489-92.

43. Knížatová M, Mihina Š, Brouček J, Karandušovská I, Sauter GJ, Mačuhová J. The influence of litter age, litter temperature and ventilation rate on ammonia emissions from a broiler rearing facility. Czech J Anim Sci 2010;55:337-45. doi: 10.17221/176/2009-CJAS

44. Matković K, Marušić D, Ostović M, Pavičić Ž, Matković S, Ekert Kabalin A, Lucić H. Effect of litter type and perches on footpad dermatitis and hock burn in broilers housed at different stocking densities. S Afr J Anim Sci 2019;49:546-54. doi: 10.4314/sajas.v49i3.15

45. Đukić Stojčić M, Bjedov S, Žikić D, Perić L, Milošević N. Effect of straw size and microbial amendment of litter on certain litter quality parameters, ammonia emission, and footpad dermatitis in broilers. Arch Anim Breed 2016;59:1317. doi: 10.5194/aab-59-131-2016

46. Avdalovic V, Vucinic M, Resanovic R, Avdalovic J, MaslicStrizak D, Vucicevic M. Effect of pelleted and chopped wheat straw on the footpad dermatitis in broilers. Pak J Zool 2017;49:1639-46. doi: 10.17582/journal. pjz/2017.49.5.1639.1646

47. Garcia MC, Leon C, Pérez P, Delgado MM. Characteristics of broiler litter using different types of materials (straw, wood shavings and rice hulls). A Castilla y Leon (Spain) case study. Proceedings of the International Symposium on Air Quality and Waste Management for Agriculture; 16-19 Sep 2007; Broomfield, Colorado; 2007. 701P0907cd. doi: 10.13031/2013.23910

48. Shepherd EM, Fairchild BD. Footpad dermatitis in poultry. Poult Sci 2010;89:2043-51. doi: 10.3382/ps.2010-00770

49. Dunlop MW, Moss AF, Groves PJ, Wilkinson SJ, Stuetz RM, Selle PH. The multidimensional causal factors of 'wet litter' in chicken-meat production. Sci Total Environ 2016;562:76676. doi: 10.1016/j.scitotenv.2016.03.147

50. Pinello CB, Richard JL, Tiffany LH. Mycoflora of a turkey confinement brooder house. Poult Sci 1977;56:1920-6. doi: 10.3382/ps. 0561920

51. So DT, Dick JW, Holleman KA, Labosky P Jr. Mold spore populations in bark residues used as broiler litter. Poult Sci 1978;57:870-4. doi: 10.3382/ps.0570870
52. Ramadan SGA, Mahboub HDH, Helal MA, Gaafar KM. Behaviour, welfare and performance of broiler chicks reared on different litter materials. Assiut Vet Med J 2013;59:9-18.

53. Terčič D, Žolger M, Pestotnik M. Effect of different litter materials on foot pad dermatitis, hock burn and feather coverage in broiler chickens. Acta Agric Slov 2015;106:97101. doi: 10.14720/aas.2015.106.2.5

54. Benabdeljelil K, Ayachi A. Evaluation of alternative litter materials for poultry. J Appl Poult Res 1996;5:203-9. doi: 10.1093/japr/5.3.203

55. Egbuta MA, Mwanza M, Babalola OO. Health risks associated with exposure to filamentous fungi. Int J Environ Res Public Health 2017;14:719. doi: 10.3390/ijerph14070719

56. Tell LA. Aspergillosis in mammals and birds: impact on veterinary medicine. Med Mycol 2005;43(Suppl 1):S71-3. doi: 10.1080/13693780400020089

57. Seyedmousavi S, Guillot J, Arné P, de Hoog GS, Mouton JW, Melchers WJG, Verweij PE. Aspergillus and aspergilloses in wild and domestic animals: a global health concern with parallels to human disease. Med Mycol 2015;53:765-97. doi: 10.1093/mmy/myv067

58. Chaudhary N, Marr KA. Impact of Aspergillus fumigatus in allergic airway diseases. Clin Transl Allergy 2011;1:4. doi: 10.1186/2045-7022-1-4

59. Kousha M, Tadi R, Soubani AO. Pulmonary aspergillosis: a clinical review. Eur Respir Rev 2011;20:156-74. doi: 10.1183/09059180.00001011

60. Mousavi B, Hedayati MT, Hedayati N, Ilkit M, Syedmousavi S. Aspergillus species in indoor environments and their possible occupational and public health hazards. Curr Med Mycol 2016;2:36-42. doi: 10.18869/acadpub.cmm.2.1.36

61. Batista BG, Chaves MA de, Reginatto P, Saraiva OJ, Fuentefria AM. Human fusariosis: an emerging infection that is difficult to treat. Rev Soc Bras Med Trop 2020;53:e20200013. doi: 10.1590/0037-8682-0013-2020

62. Frisvad JC, Hubka V, Ezekiel CN, Hong S-B, Nováková A, ChenAJ, Arzanlou M, Larsen TO, Sklenáŕ F, Mahakarnchanakul W, Samson RA, Houbraken J. Taxonomy of Aspergillus section Flavi and their production of aflatoxins, ochratoxins and other mycotoxins. Stud Mycol 2019;93:1-63. doi: 10.1016/j. simyco.2018.06.001

63. Varga J, Baranyi N, Chandrasekaran M, Vágvölgyi C, Kocsubé S. Mycotoxin producers in the Aspergillus genus: an update. Acta Biol Szeged 2015;59:151-67.

\section{Razlike u onečišćenju stelje gljivicama tijekom tova pilića između ljetnog i zimskog razdoblja}

Cilj ovoga rada bio je usporediti onečišćenje stelje za perad gljivicama između toplog i hladnog razdoblja godine. Istraživanje je provedeno u komercijalnim uvjetima proizvodnje tijekom petotjednog tova pilića ljeti (srpanj - kolovoz) i zimi (prosinac - siječanj). Pilići su držani na stelji od sjeckane slame i piljevine. Koncentracija i sastav gljivica u stelji istraživani su tjedno, zajedno s temperaturom, vlagom i pH stelje. Ukupna koncentracija gljivica u stelji povećavala se tijekom tova u oba godišnja razdoblja, bez utvrđenih razlika u prosječnim koncentracijama između razdoblja. Razdoblje godine također nije imalo utjecaja na koncentracije kvasaca, aspergila iz sekcije Nigri te Cladosporium, Fusarium i Rhizopus spp., a koncentracije aspergila iz sekcije Flavi, kao i ukupnih aspergila u stelji bile su veće u ljetnom, a koncentracije Mucor i Penicillium spp. u zimskom razdoblju. Utvrđena je visoka pozitivna povezanost ukupne koncentracije gljivica s temperaturom, vlagom i pH stelje, neovisno o razdoblju godine. Dobiveni rezultati mogu biti korisni u procjeni i kontroli potencijalnoga štetnog učinka gljivica na zdravlje peradi i radnika na peradarskim farmama.

KLJUČNE RIJEČI: hladno razdoblje; mikoflora; perad; pH; temperatura; toplo razdoblje; vlaga 